\title{
Creativity and Complex Thoughts of Gifted Students from Contributions of Edgar Morin and Rudolf Steiner
}

\author{
Fernanda Hellen Ribeiro Piske1, Tania Stoltz ${ }^{1}$, Ettiène Guérios ${ }^{1}$, Samarah Perszel de Freitas ${ }^{2}$ \\ ${ }^{1}$ Federal University of Paraná, Curitiba, Brazil \\ ${ }^{2}$ Positivo University, Curitiba, Brazil \\ Email: nandahellen@hotmail.com
}

How to cite this paper: Piske, F. H. R., Stoltz, T., Guérios, E., \& de Freitas, S. P. (2016). Creativity and Complex Thoughts of Gifted Students from Contributions of Edgar Morin and Rudolf Steiner. Creative Education, 7, 2268-2278.

http://dx.doi.org/10.4236/ce.2016.715221

Received: July 4, 2016

Accepted: September 24, 2016

Published: September 27, 2016

Copyright $\odot 2016$ by authors and Scientific Research Publishing Inc. This work is licensed under the Creative Commons Attribution International License (CC BY 4.0).

http://creativecommons.org/licenses/by/4.0/

\begin{abstract}
This study aims to highlight the importance of creativity in education of gifted children. Gifted students are generally individuals that talk with uncertainty because they are always looking for solutions and discoveries for their varied researches in their area of interest. These students need educational practices that develop creativity and enable to incite their complex thinking. These practices require measures that instigate their curiosity and promote activities that represent challenges during classes. Creativity is essential for their education because the development of creativity in teaching can generate possibilities of well-being for it arouses curiosity, excitement and desire to learn from each individual. It is important that teachers are prepared to attend these children and encourage gifted students to have a creative and autonomous spirit and exercise a critical and reflective thinking about the process of teaching and learning.
\end{abstract}

\section{Keywords}

Gifted Students, Complexity, Creativity, Rudolf Steiner, Edgar Morin

\section{Introduction}

In the school context, it is possible to notice a resistance by some teachers to understand the creative and complex thinking of gifted students. Bahia \& Trindade (2013, 2014), Alencar (2009) express that the teaching staff, in general, is not prepared to attend gifted students and emphasize the importance of creative thinking regarding the amount of detail contained in an idea; infrequent or unusual responses; ability to change the thinking or design different response categories; decision process, judgment 
and selection of one or more ideas previously submitted and also the abundance or quantity of different ideas on the same subject (Alencar, 2009: p. 31).

Piske, Stoltz, \& Machado (2014) express the lack of motivation that a repetitive teaching can cause to the gifted students, "creativity is not being developed as it should be. Most students often feel unmotivated because of a monotonous and repetitive teaching" (Piske, Stoltz, \& Machado, 2014: p. 348).

The way how these students solve problems is not linear and is much more complex than it seems and their creativity in finding ways to resolve their activities goes far beyond standard education. Understanding the creativity of gifted students is complex and depends on many issues.

Martínez (1997: p. 125) explains that the complexity of psychological determination of creativity cannot be understood only by psychometric studies or partial trial, which, due to its quantitative or relatively artificial character, is too limited to understand its essence.

Educational practices that develop creativity and enable to incite complex thinking of gifted students require measures that instigate their curiosity and promote activities that represent challenges during classes.

Generally gifted students are individuals that talk with uncertainty because they are always looking for solutions, discoveries for their varied researches in their area of interest. For Morin (2014), talk with uncertainty means to seek truths to issues preconceived, i.e., there is no absolute truth, but rather opportunities to understand the truths in different areas of knowledge.

Morin $(1977,1980,1999)$ affirms that knowing and thinking do not reach an absolutely certain truth, but talking with uncertainty. In consonance with this thinking that there is no absolute truth and it is important to respect the different views on knowledge, Steiner $(1988,1997,2000,2012)$, founder of Waldorf education, points out that each person can have a different point of view from other individuals, but it is important that other individuals identify what is right by himself/by herself, it is essential to contribute a little to help him/her to do this.

It means that even if there are disagreements, knowledge is built together, and there is no absolute truth. Therefore, if gifted students can get a variety of solutions to some problems through their creativity, it is important to respect their complex thinking.

In addition to the rationality that exists in education, educational practices should include ways to create emotional ties between individuals involved in the process of teaching and learning.

According to Morin (1999), affection is very important during education. It internalizes the events and disturbances from outside and "This means that the brain computation always finds itself, simultaneously, in a state of knowledge, of sensitivity and action" (Morin, 1999: p. 207), for Steiner (1988, 2012), the true self-knowledge is only given to human being when he/she develops affectionate interest for the other individuals.

The human being only reaches true knowledge of the world when somebody tries to 
understand his/her own being. It is important to make gifted students recognize their potential and motivate them to make researches about the area of their interests. Selfknowledge is a way to reflect about their own potential, but also about their own educational needs, difficulties and limitations.

\section{The Importance of Creativity during the Process of Teaching and Learning}

The relationship between imagination and creativity is explained in the creation process. Both creativity and imagination are aspects of the creation process. Creativity is the quality to create, whereas the imagination can be considered as the action to imagine and invent something new.

The development of creativity in teaching can generate possibilities of well-being because it arouses curiosity, excitement and desire to learn of each individual (Piske, 2014). An interesting way is to work with creative and artistic activities. Stoltz \& Weger $(2012,2015)$ highlight the importance of art to develop the creativity of each person. "Art is the dimension where man rises from creature to creator, but it is not removed from nature. It demands a worthy contemplator, and involves maturing" (Stoltz \& Weger, 2012: p. 135).

For Morin (2000a, 2000b), creativity is not widely developed at school, on the contrary, school work is done in a piecemeal way, it does not allow the individual to work with a vision of the whole.

It is important to establish relations, taking into account the dimensions that compose the same area of knowledge, presenting different points of view for each question. According to Morin $(2007,2014)$, is a challenge for education to achieve understanding of the complexity of things. Morin (1980) considers the complexity as a new category essential for understanding of new paradigm. The real is complex. The phenomenon of self-production and self-organization develops itself in these organisms from the non-dynamic equilibrium that seeks new adaptations (Morin, 1980: pp. 335-393). Regarding complexity, Morin (2007) points out:

Complexity presents itself with the disturbing traits of a mess, of the inextricable, of disorder, of ambiguity, of uncertainty. Hence the necessity to put phenomena in order by repressing disorder, by pushing aside the uncertain. In other words, to select the elements of order and certainty, and to eliminate ambiguity, to clarify, distinguish, and hierarchize. But such operations, necessary for intelligibility, risk leading us to blindness if they eliminate other characteristics of the complexus. And in fact, as I have argued, they have made us blind (Morin, 2007: pp. 13-14).

The complexity of looking at things differently comes from the realization that every human being is able to use creativity to solve problems in various ways and discover a range of possibility of solutions for the different areas of knowledge. Each individual is endowed with intelligence, emotions and feelings, and his/her imagination can be expressed in different ways. Morin (2000a) explains: The importance of fantasy and im- 
agination in humans is fundamental for their existence; since the routes of entry and exit of neuro cerebral system that put the body in connection with the outside world, account for only $2 \%$ of the total, while $98 \%$ refers to the internal operation, constituted a relatively independent psychic world, where ferments needs, dreams, desires, ideas, images, fantasies, and this world seep into our vision or conception of the outside world (Morin, 2000a: p. 21).

Steiner $(1988,1997,2015)$ explains the imagination as something that emerges from the perception through the senses. A work that develops creativity involves important aspects such as emotions, fantasy and imagination of each person. Imagination creates possibilities for invention, creation and achievement of new discoveries. Van Alphen (2011: p. 17) expressed

Steiner (1996: pp. 55-57) describes imagination as emerging from perception by means of the senses, causing an active thinking process to create what he terms "living pictures" in the mind of the observer. These "living pictures" are flexible perceptions, able to expand and be refined as and when further experiences present themselves.

Van Alphen (2011) explains that Steiner meticulously observed the nature of thinking, feeling and will in human being, with its higher manifestations of imagination, inspiration and intuition respectively. Van Alphen points out that the educational theory of Steiner originated from these observations.

Regarding the "spiritual" aspect, Steiner refers to the individuality of each human being, from which ethical and enduring values can be developed. Steiner considers imagination, inspiration and intuition as spiritual and essential qualities to the development of human potential. Van Alphen (2011: p. 23) highlights

Steiner regarded himself as a researcher of the "spiritual" nature of the human being, using scientific research methods to explore human experience and development. By "spiritual", Steiner refers to the core individuality of a human being, from which ethical and lasting values and the pursuit of all "knowing" originates. He attributes imagination, inspiration and intuition as spiritual qualities, and as essential to the unfolding of human potential.

Morin also emphasizes the importance of imagination in teaching. According to Morin (2000a), it is important that education provides natural ability of the mind to formulate and solve fundamental problems and, in an integrated manner, incite the full use of intelligence. This full use requires freedom of expression, free exercise of curiosity, imagination and creativity. It is fundamental the acquisition of knowledge based on conjunctions that allow relating the multidimensionality of context, and then highlighting the complexity of it.

\section{What Is a Relevant Knowledge?}

Quality education presupposes the access to global knowledge. The relevant knowledge is that which enables to understand what is complex. To educate students it is impor- 
tant to teach the integrated human condition in the most diverse areas of knowledge, placing the individual in the universe, and not separating it from him/her. In this sense it is essential to provide ways for reforming thought (Morin, 2000a).

Regarding gifted students, Piske \& Bahia (2012) explain that their creative potential has not been properly worked in the classroom because of the lack of proper training of their teachers or absence of a specialized service that attends every dimension of their development. School teaching presented to gifted students, in general, has not attended their educational needs and has inhibited their creativity, their imagination and fantasy.

Understanding the complex thinking of gifted requires a change of paradigm. Regarding the paradigm, Morin (2000b) points out that there is an old paradigm, an old principle that leads us to simplify, segregate, reduce and formalize without express what is separated and without generating the sets or the complexity of reality. The old paradigm is related to an education that makes students just reproduce what teachers teach them without reflecting about knowledge.

According to Morin (2000a), the paradigm accomplishes the selection and determination of conceptualization and logical operations; this represents the key categories of intelligibility and operates the control of its function. "This way, individuals know, think, and act according to paradigms registered in them culturally" (Morin, 2000a: p. 25).

The paradigm of complexity is related to transdisciplinarity that is a scientific approach seeking the unity of knowledge. This approach aims to provide a new understanding of reality articulating elements that pass between, beyond and across disciplines. Petraglia (1995) elucidates that the thought is not static, it indicates movement; and this coming and going that enables the creation and with it the development of knowledge. This is what justifies the disruption of the individual with linear and reductionist thought in the paradigm of simplicity, focusing on the present, the paradigm of complexity (Petraglia, 1995: p. 69). Petraglia states that "transdisciplinarity is the result of the complexity paradigm, based on an epistemology of complexity, also being present in its source the interlinkages of subject-object-environment" (Petraglia, 1995: p. 75).

In turn, Steiner $(2000,2012,2015)$ highlights the importance of overcoming the reductionist paradigm, and points to a holistic education that emphasizes the development of the whole human being; such education is focused beyond the intellectual dimension, integrating the emotional, social, physical, creative/intuitive, aesthetic and spiritual aspects.

\section{Need for Changing the Paradigm}

The change of paradigm is complex since paradigm is a whole constellation of beliefs, values and methods, with the participation by the members of a determined society (Kuhn, 1970: p. 175). So it is evident that each culture establishes its way of interpreting, evaluating and intervening on certain area of knowledge. What we see is that there is still resistance to change and to invest in creativity and innovation in different social 
contexts.

In the educational context there is a resistance to change the way of teaching and this fact ends up making the tiring and tedious teaching. The antigen of change remains in society and education, then it is important to find a way to overcome, believe and put into practice educational measures to work creatively. Kegan \& Lahey (2000) explain:

If we want to understand the development of change, we should pay more attention to our powerful inclinations to not change. This attention will help us to discover within ourselves the strength and beauty of a hidden immune system, the dynamic process by which we tend to prevent the change, whereby continually we manufacture the antigens of change. If we can unlock this system, we will release new energy to support new ways of seeing and being (Kegan \& Lahey, 2000: p. 56).

This paradigm that simplifies standardizes and reduces teaching ends up limiting the creative potential of gifted students that in most cases are not included at school. "Gifted children are not only faster than normal children but they are also different because they require minimal structured support, because they can make their own discoveries" (Winner, 1998: p. 247).

\section{The Complexity of Inclusion of Gifted Students at School}

The complexity of educating a student with high potential is far greater than the teaching staff thinks; it is a challenge that has not often been discussed efficiently in the school context, much less overcome because of the conditions of inclusion offered by the school.

If there is discussion about inclusion of gifted students, there are two questions that are often asked by teachers. On the one hand this discussion is controversial among professionals of education believing that gifted students do not need specialized service, on the other hand an effective solution does not appear to attend the special educational needs of these students.

National and International Studies (Bahia, 2016; Dufour, 1998; Alencar, 2001, 2014; Renzulli, 2005; Besançon \& Lubart, 2008; Pfeiffer, 2016; Piske \& Stoltz, 2013; Piske, 2014; Gross, 2014, 2016; Kane \& Silverman, 2014; Kane, 2016; Miranda \& Morais, 2014, among other authors) highlight that gifted students, despite having high skills/gif- tedness $(\mathrm{AH} / \mathrm{SD})$, require specialized service and may have educational needs in every dimension of development.

These needs are related to cognitive, affective and social aspects, that is, It would be necessary an education that aims to attend all aspects of development, both authors Morin $(1977,1979,1980,1998)$ and Steiner $(1988,1997,2003,2005)$ point out the importance of having an education that attend students integrally, avoiding reductionist and fragmented way of teaching that is present in the school context.

\section{Some Possibilities to Work with Creativity in the School Context}

Working with creativity would be an important way to attend the development of each 
student integrally. Wechsler (1998), Piske (2014), Bahia \& Trindade (2013) indicate ways to work with creative potential, focusing on freedom of expression during the teaching and on mutual respect, which can generate opportunities to recognize the different opportunities during the process of teaching and learning. Among them, it is possible to list:

- Provide students the freedom to choose between different ways to solve a problem by diversifying the possibilities of carrying out a proposed activity.

- Help students to express different ideas of yours; provide environments exploration opportunities, leaving whenever possible the limited physical space of the classroom.

- Encourage students to do their personal projects as a means to recognize their skills and talents; encourage them to be questioners.

- Allow students to make questions and test their hypotheses, even if they seem inadequate or absurd at first.

- Encourage curiosity for learning and discourage the focus on memorization.

- Give options to students to make researches about different areas of knowlegde, among other possibilities to work with creativity.

\section{Conclusions}

It is possible to conclude that the challenge to understand the complex thinking of gifted students at school depends on the formation of the teaching staff to carry out proper planning of classes according to their special educational needs. This planning should be based on classes with creative activities and should also incite curiosity and interest of these students who need specialized service.

Educational practices that include working with creativity only happen if there is a good training of teachers who are willing to accept a creative education and work innovatively. One of the school's challenges is to create opportunities of learning that encourage the development of creative potential not only of students but also of teachers (Fleith, 2011: p. 35).

The complexity in understanding the thinking of students with high potential may be greater than we think. According to Alencar \& Martinez (1998: p. 31), the development of creativity in education passes necessarily by the level of creativity of the professionals who work at school. Teachers should know the barriers they face during the process of teaching and learning, this can be a necessary condition to overcome the difficulty to work with creativity.

Piske \& Stoltz (2014) point out that the artistic approach of Waldorf education leads to a form of education that does not reproduce dead concepts, but it takes to flexible and dynamic concepts, this is essential in today's world. These concepts emerge for creating vivid images and from a living relationship with teachers who work with sensations and mental representations that can grow in images.

Current education promotes the division of knowledge; IT operates in a fragmented way and ends up limiting the creativity of students with high potential. 
Morin (2002) explains that the division of knowledge into disciplines, that enables the development of knowledge, "is an organization that makes impossible the knowledge of knowledge, because knowledge remains fragmented in fields of knowledge that are not communicants" (Morin, 2002: p. 20).

Morin (2014) emphasizes that, to a large extent, the fragmentation of knowledge is related to the predominance of partial intelligence. According to Morin (1977, 1979, $1980,1998)$ and Steiner $(1988,1997,2003,2005)$, we should overcome the existing reductionist view in education and expand the possibilities of working with innovation, invention, imagination and creativity.

Rudolf Steiner presents a novel form of integration of thinking, feeling and desire through creative and artistic activities in Waldorf Pedagogy. And this integration has a clear intention: the development of an ethical freedom, considering both the individual and society and nature (Veiga \& Stoltz, 2014; Veiga, 2015; Stoltz, Veiga, \& Romanelli, 2015; Stoltz \& Weger, 2015).

It is important to encourage gifted students to have a creative and autonomous spirit and exercise a critical and reflective thinking about the process of teaching and learning. In this sense, Bahia \& Trindade (2013), Wechsler (1998), Miranda \& Morais (2014), Piske (2014) highlight the importance of creating a stimulating environment where the teaching team has freedom of speech. Teachers should allow their students to express different ideas of theirs, provide opportunities of researches in the educational environment, and give the students freedom to choose different ways to solve a problem. Thus, the complex thought can go beyond the limits imposed by standardized education, enabling the development of creative potential.

\section{References}

Alencar, E. M. L. S., \& Martinez, A. M. (1998). Barreiras à expressão da criatividade entre profissionais brasileiros, cubanos e portugueses. Psicologia Escolar e Educacional, 2, 23-32. http://dx.doi.org/10.1590/S1413-85571998000100003

Alencar, E. M. L. S. (2001). Criatividade e educação de superdotados. Petrópolis, RJ: Vozes.

Alencar, E. M. L. S. (2014). Ajustamento Emocional e Social do Superdotado: Fatores Correlatos. In F. H. R. Piske, J. M. Machado, S. Bahia, \& T. Stoltz (Orgs.), Altas habilidades/ Superdotação (AH/SD): Criatividade e emoção (Giftedness: Creativity and Emotion) (pp. 149-162). Curitiba: Juruá.

Bahia, S., \& Trindade, J. P. (2013). Transformar o velho em novo: a integração da criatividade na educação. In F. H. R. Piske, \& S. Bahia (Orgs.), Criatividade na escola: O desenvolvimento de potencialidades, altas habilidades e talentos (Creativity at School: Development of Potentials, High Abilities and Talents) (pp. 15-32). Curitiba: Juruá.

Bahia, S., \& Trindade, J. P. (2014). A importância da cooperação na sobredotação. In F. H. R. Piske, J. M. Machado, S. Bahia, \& T. Stoltz (Orgs.), Altas habilidades/Superdotação (AH/SD): Criatividade e emoção (Giftedness: Creativity and Emotion) (pp. 115-126). Curitiba: Juruá.

Besançon, M., \& Lubart, T. (2008). Individual Differences in the Development of Creative Competencies in School Children. Learning and Individual Differences, 18, 381-389.

http://dx.doi.org/10.1016/j.lindif.2007.11.009 
Dufour, V. (1998). Intelligence et adaptation: Les enfants intellectuellement surdoués en situation d'inadaptation. Journal des psychologues, No.154, 52-53.

Fleith, D. S. (2011). Desenvolvimento da criatividade na educação fundamental: Teoria, pesquisa e prática. In . M. Weschsler, \& V. L. T. Souza (Orgs.), Criatividade e aprendizagem: Caminhos e descobertas em perspectiva internacional (pp.33-52). São Paulo: Edições Loyola.

Gross, M. U. M. (2014). Issues in the Social-Emotional Development of Intellectually Gifted Children. In F. H. R. Piske, J. M. Machado, S. Bahia, \& T. Stoltz (Orgs.), Altas habilidades/Superdotação (AH/SD): Criatividade e emoção (Giftedness: Creativity and Emotion) (pp. 85-96). Curitiba: Juruá.

Gross, M. U. M. (2016). Developing Programs for Gifted and Talented Students. In F. H. R. Piske, T. Stoltz, J. M. Machado, \& S. Bahia (Orgs.), Altas habilidades/Superdotação (AH/SD) e Criatividade: Identificação e Atendimento. (Giftedness and Creativity: Identification and Specialized Service) (pp. 61-76). Curitiba: Juruá.

Kane, M., \& Silverman, L. K. (2014). Fostering Well-Being in Gifted Children: Preparing for an Uncertain Future. In F. H. R. Piske, J. M. Machado, S. Bahia, \& T. Stoltz. (Orgs.), Altas habilidades/Superdotação (AH/SD): Criatividade e emoção (Giftedness: Creativity and Emotion) (pp. 67-84). Curitiba: Juruá.

Kane, M. (2016). Gifted Learning Communities: Effective Teachers at Work. In: F. H. R. Piske, T. Stoltz, J. M., Machado \& S. Bahia. (Orgs.), Altas habilidades/Superdotação (AH/SD) e Criatividade: Identificação e Atendimento (Giftedness and Creativity: Identification and Specialized Service) (pp. 77-94). Curitiba: Juruá.

Kegan, R. L., \& Lahey, L. (2000). How the Way We Talk Can Change the Way We Work: Seven Languages for Transformation. Chicago, IL: Jossey-Bass.

Kuhn, Thomas (1970). Estrutura das revoluções científicas. Chicago, IL: University Chicago.

Martínez, A. M. (1997). Criatividade, Personalidade e Educação. Campinas: Papirus.

Miranda, L. C., \& Morais, M. F. (2014). Enriquecimento criativo e sua promoção em alunos sobredotados. In F. H. R. Piske, T. Stoltz, J. M. Machado \& S. Bahia. (Orgs.), Altas habilidades/Superdotação (AH/SD): Criatividade e emoção [Giftedness: Creativity and Emotion] (pp. 185-212). Curitiba: Juruá.

Morin, E. (2007). Introdução ao pensamento complexo. Porto Alegre: Sulina.

Morin, E. (1977). O Método I: A Natureza da Natureza (2nd ed., 363 p). Lisboa: Publicações Europa América.

Morin, E. (1979). O enigma do homem: Para uma nova antropologia (2nd ed., 227 p). Tradução de Fernando, C. F., Rio de Janeiro: Zahar Editores.

Morin, E. (1980). La méthode 2: La vie de la vié. Paris: Suil.

Morin, E. (1998). Amor, Poesia, Sabedoria (72 p). Rio de Janeiro: Bertrand. Brasil.

Morin, E. (1999). O Método II-A vida da vida. Portugal: Publicações Europa-América.

Morin, E. (2000a). Os sete saberes necessários à educação do futuro (118 p). Tradução de Catarina, E. F. and da Silva, J. S., revisão técnica de Edgard de Assis, C., São Paulo: Edições UNESCO Brasil.

Morin, E. (2000b). A cabeça bem feita: repensar a reforma, reformar o pensamento (128 p). Tradução de Eloá, J., Rio de Janeiro: Bertrand Brasil.

Morin, E. (2014). Ciência com Consciência (2. ed., 350 p). Rio de Janeiro: Bertrand Brasil.

Petraglia, I. C., \& Morin, E. (1995). A educação e a complexidade do ser e do saber (6th ed.). Petrópolis: Vozes. 
Pfeiffer, S. (2016). Leading Edge Perspectives on Gifted Assessment. In F. H. R. Piske, T. Stoltz, J. M. Machado \& S. Bahia. (Orgs.), Altas habilidades/Superdotação (AH/SD) e Criatividade: Identificação e Atendimento [Giftedness and Creativity: Identification and Specialized Service] (pp. 95-122). Curitiba: Juruá.

Piske, F. H. R., \& Bahia, S. (2012). Criatividade e Inovação: A Importância de uma boa formação docente para desenvolver as Altas Habilidades. In L. Almeida, S. Bahia, \& S. Caires (Orgs.), Actas do I Seminário Internacional “Contributos da Psicologia em Contextos Educativos" (pp. 79-86). Braga: Universidade do Minho.

Piske, F. H. R., \& Stoltz, T. (2013). Criatividade na escola: A necessidade de reavaliar as práticas educacionais aos alunos superdotados. In F. H. R. Piske, \& S. Bahia (Orgs.), Criatividade na escola: o desenvolvimento de potencialidades, altas habilidades/superdotação (AH/SD) e talentos [Creativity at School: Development of Potentials, High Abilities and Talents] (pp.141158). Curitiba, Juruá.

Piske, F. H. R., \& Stoltz, T. (2014). Ciência e arte na educação de superdotados. Um olhar a partir de Steiner. In M. Veiga, \& T. Stoltz (Orgs.), O pensamento de Rudolf Steiner no debate científico (pp. 165-180). Campinas: Editora Alínea.

Piske, F. H. R. (2014). Criatividade e Inovação na educação de superdotados. In F. H. R. Piske, J. M. Machado, S. Bahia, \& T. Stoltz. (Orgs.), Altas habilidades/Superdotação (AH/SD): Criatividade e emoção [Giftedness: Creativity and Emotion] (pp. 265-276). Curitiba: Juruá.

Piske, F. H. R., Stoltz, T., \& Machado, J. M. (2014). Creative Education for Gifted Children. Creative Education, 5, 347-352. http://dx.doi.org/10.4236/ce.2014.55044 http://www.scirp.org/journal/PaperInformation.aspx?PaperID=45206

Renzulli, J. S. (2005). The Three-Ring Conception of Giftedness: A Developmental Model for Creative Productivity. In: R. Sternberg, \& J. Davidson (Eds.), Conception of Giftedness (pp. 5392). Cambridge: University of Cambridge. http://dx.doi.org/10.1017/CBO9780511610455.015

Steiner, R. (1988). A arte da educação I: o estudo geral do homem. São Paulo: Antroposófica.

Steiner, R. (1997). Antropologia meditativa: Contribuição à prática pedagógica: Quatro conferências proferidas em Stuttgart (Alemanha) de 15 a 22 de setembro de 1920. São Paulo: Antroposófica.

Steiner, R. (2000). A filosofia da liberdade: Fundamentos para uma filosofia moderna. Resultados com base na ciência pensante, segundo o método das ciências naturais. São Paulo: Antroposófica.

Steiner, R. (2003). A arte da educação II: Metodologia e didática (2nd ed.). São Paulo: Antroposófica.

Steiner, R. (2005). Curso de pedagogia curativa: doze palestras proferidas em Dornach, 25 de junho e 7 de julho de 1924, para médicos e pedagogos curativos: GA 317. São Paulo: Federação das Escolas Waldorf no Brasil.

Steiner, R. (2012). A educação da criança segundo a Ciência Espiritual (3rd ed.). São Paulo: Antroposófica.

Steiner, R. (2015). Educação na puberdade: o ensino criativo (4th ed.). São Paulo: Antroposófica.

Stoltz, T., \& Weger, U. (2015). O pensar vivenciado na formação de professores. Educar em Revista, 67-83. http://dx.doi.org/10.1590/0104-4060.41444

http://www.scielo.br/scielo.php?script=sci_arttext\&pid=S0104-40602015000200067\&lng=pt\&tl $\underline{\text { ng}}=$ pt.10.1590/0104-4060.41444

Stoltz, T., \& Weger, U. (2012). Piaget and Steiner: Science and Art in the Process of Formation. Research on Steiner Education (RoSE), 3, 134-145.

http://www.rosejourn.com/index.php/rose/article/viewFile/106/131 
Stoltz, T., Veiga, M., \& Romanelli, R. A. (2015). Apresentação. Educar em Revista, 15-18. http://dx.doi.org/10.1590/0104-4060.41831

http://www.scielo.br/scielo.php?script=sci_arttext\&pid=S0104-40602015000200015\&lng=en\&t lng=pt.10.1590/0104-4060.41831

Van Alphen, P. (2011). Imagination as a Transformative Tool in Primary School Education. Research on Steiner Education (RoSE), 2, 16-34.

Veiga, M., \& Stoltz, T. (Orgs.) (2014). O pensamento de Rudolf Steiner no debate científico. Campinas, SP: Editora Alínea.

Veiga, M. (2015). Revisiting Humanism as Guiding Principle for Education: An Excursion into Waldorf Pedagogy. Educar em Revista, 56, 19-31. http://dx.doi.org/10.1590/0104-4060.41417 http://www.scielo.br/scielo.php?script=sci_arttext\&pid=S0104-40602015000200019\&lng=pt\&tl ng=en.10.1590/0104-4060.41417

Wechsler, S. M. (1998). Criatividade: Descobrindo e encorajando. São Paulo: Psy.

Winner, E. (1998). Crianças superdotadas: Mitos e realidades. Porto Alegre: Artes Médicas.

Submit or recommend next manuscript to SCIRP and we will provide best service for you:

Accepting pre-submission inquiries through Email, Facebook, LinkedIn, Twitter, etc. A wide selection of journals (inclusive of 9 subjects, more than 200 journals)

Providing 24-hour high-quality service

User-friendly online submission system

Fair and swift peer-review system

Efficient typesetting and proofreading procedure

Display of the result of downloads and visits, as well as the number of cited articles

Maximum dissemination of your research work

Submit your manuscript at: http://papersubmission.scirp.org/

Or contact ce@scirp.org 